\title{
Sri Lanka i fredens skygge
}

\section{Anna von Sperling}

\section{En endelig løsning på konflikten mellem tamilerne og Sri Lankas regering er ikke fundet og våbnene kan derfor lyne igen, hvis det internationale sam- fund fortsat vender det blinde øje til}

Man er nået et godt stykke, når en borgerkrig bliver omtalt i datid. Men på mange måder er det først der, den egentlige kamp begynder. Det er i hvert fald tilfældet i Sri Lanka. Den krig, der i 26 år har hærget østaten og kostet mindst 70.000 dræbte, primært fra det tamilske mindretal, blev erklæret officielt ovre for to år siden. Desværre tyder meget på, at Sri Lanka er længere fra forsoning mellem det etniske mindretal af tamilere og den srilankanske stat end nogensinde.

For mens verden meget hurtig syntes at vænne sig til, at konflikten mellem de Tamilske Tigre (Liberation Tigers of Tamil Eelam, LTTE) og regeringen i Colombo officielt er ovre, er forholdene for landets tamilske mindretal langtfra normaliseret. Som International Crisis Group gør opmærksom på i sin seneste rapport om Sri Lanka: "I modstrid med det image, som den ønsker at vise, har den srilankanske regering i stigende omfang afskåret minoriteterne og politiske modstanderes mulighed for at deltage i beslutningerne om deres $\varnothing$ konomiske og politiske fremtid, frem for at arbejde for forsoning."

Og på mange områder lever landets tamilske mindretal stadig, som var krigen aldrig afsluttet. Den britiske NGO Stop Torture Now offentliggjorde i november en rapport, der dokumeterer fortsat tortur mod mistænkte politisk aktive tamilere, begået af politiet og militæret. De undtagelses- og terrorlove, der blev skabt under krigen, er i vid udstrækning stadig ved magt. I den tidligere LTTE-dominerede nordøstlige del af øen går det langsomt med genopbygningen, internationale organisationer klager stadig over svære arbejdsvilkår, og administrationen, som LTTE tidligere stod for, er overgivet til hæren. Flere NGO'er på- 
peger, at opbygningen af en egentlig civil administration trækker mistænksomt i langdrag, hvilket ikke alene betyder, at de civile tamilere skal se deres liv administreret af den hær, som så mange har utrolig dårlige oplevelser med. Men det forhindrer også, at man kan udnytte den lokale kapacitet, der blev opbygget under LTTE-kontrol samt uddanne den store gruppe af unge mennesker, der ikke kender til andet end at slås. Og pressen er underlagt hård kontrol.

\section{Retfærdighed}

Disse er alle sammen forhold, der forringer tilværelsen for mange og hele tiden øges muligheden for, at den væbnede konflikt igen bryder ud. Og intet tyder til nu på, at de skyldige for massakrerne i krigens afsluttende måneder bliver stillet til regnskab. Regeringen med præsident Mahinda Rajapakse i spidsen anerkender ikke et eneste fejltrin eller synes indstillet på at tage hensyn til tamilernes drømme og ønsker. For - vigtigst af alt - er der ikke blevet taget fat om konfliktens rod: At en betydelig del af landets befolkning ønsker øget selvstyre så stærkt, at de vil dø for den - eller sende andre folks børn ud og dø for den.

Krigens afslutning har forbedret livet for store dele af landets befolkning. Helt afgørende er, at sikkerheden er øget markant for den overvejende singalesiske befolkning i Syd, der ikke længere skal frygte de før alt for hyppige eksempler på tigernes 'specialitet', selvmordsbomber. Ligeledes kan den tamilske befolkning i nord og øst endelig slippe frygten for overgreb fra LLTT, herunder den tidligere overhængende fare for at få tvangsindrulleret deres børn i oprørshæren.

Men på en lang række andre områder er alt som før. Og i nogle tilfælde værre. Skal Sri Lanka videre og skal der skabes grundlag for en forsoningsproces, er det helt afgørende, at regeringen og hæren stilles til ansvar. En række af de interne processer kan godt nok bakkes op gennem $\mathrm{fx}$ målrettet bistand til civilsamfundet. Men i spørgsmålet om krigsforbrydelser kan og skal resten af verden spille en aktiv rolle for at give det tamilske mindretal en fornemmelse af, at de ikke er glemt, og at retfærdighed også tilkommer $\mathrm{dem}$, når vores fælles regler for krig trædes under fode.

\section{Overgreb}

Den endelige nedkæmpning af De Tamilske Tigre i foråret 2009 skete med kolossal brutalitet over for civile tamilere. En rapport fra FN konkluderede i år, at den srilankanske hærs militære sejr i maj 2009 dækkede over et utal af grove krigsforbrydelser. Rapporten, der er resultat af et tremandspanels 10 måneders undersøgelser i østaten, beskriver, hvordan regeringshæren 
systematisk bombede hospitaler, FNkvarterer og skibe, der tilhørte internationale humanitære organisationer.

Rapporten slår også fast, at 'titusinder' blev dræbt mellem januar og maj 2009. Den beskriver, hvordan civile blev likvideret med pandeskud og kvinder blev voldtaget af regeringssoldater, mens modstanderen LTTE placerede 330.000 civile som bombeskjold. Rapportens forfattere konkluderer, at "troværdige beskyldninger, der hvis de bliver bevist, indikerer, at der er foregået en bred vifte af alvorlige brud på folkeretten, blev begået af både den srilankanske regering og LTTE. Nogle af dem kan betegnes som krigsforbrydelser og forbrydelser mod menneskeheden."

Ikke overraskende forsøgte den srilankanske regering med næb og klør at bremse rapporten "af hensyn til freds- og genforeningsprocessen," lød forklaringen. "Offentliggørelse af denne rapport vil gøre ubodelig skade på bestræbelserne på at skabe forsoning i Sri Lanka. Den vil også skade FN-systemet", udtalte Sri Lankas udenrigsminister, G.L. Peiris.

\section{Frygtelige billeder}

I første omgang afviste FN's generalsekretær Ban Ki Moon, at FN kunne gøre andet end at opfordre til, at Sri Lanka på eget initiativ iværksatte en undersøgelse. Presset blev øget, da den britiske tv-kanal Channel 4 viste en dokumentarfilm om krigens sidste uger. Det er frygtelige billeder, optaget med primært mobiltelefoner, og et langt stykke hen ad vejen af bødlerne selv. Det er billeder af systematiske henrettelser af fanger og civile, der søgte hjælp, af maltrakterede kvindelig med tydelige tegn på grove seksuelle overgreb og sønderbombede felthospitaler med døde børn på gulvene. I ugerne, der fulgte, sendte kampe op mod 400.000 civile på flugt, først i store flokke i alle retninger, men da regeringen udpegede et område som 'sikkerhedszone', blev de samlet. Men sikkerhedsløfterne holdt ikke. Dagligt blev lejrene bombet, og ikke mindst de interimistiske felthospitaler, der i forvejen var afskåret fra både mad og medicin, stod for skud. Efter 64 angreb på hospitaler appellerede lokale læger til Internationalt Røde Kors, der i krigssituationer rejser rundt og indsamler GPS-koordinater på hospitaler, så angrebshæren kan undgå dem, om ikke at udlevere flere lokaliteter til regeringshæren. Der blev nemlig bombet en time efter.

I dagene før den endelige 'sejr' blev annonceret 18. maj 2009, var de sidste flygtninge samlet på en lille sandtange uden muligheder for at komme væk. Ifølge den srilankanske hær var der 10.000. Ifølge vidner 100.000 mennesker. Hvor mange, der slap væk, vides ikke, men FN's tidligere talsmand i området er ikke i tvivl om, hvorfor det 
officielle tal er så lavt. Så skulle de ikke stå til regnskab for hvor mange, de dræbte. Ifølge FN blev 40.000 mennesker fra det tamilske mindretal slagtet på tre uger.

\section{FN's ansvar}

Og mens billederne og dødstallene i sig selv er rystende, bliver historien næsten ubærlig af det faktum, at FN var til stede og havde lovet de civile tamilere, at de ville blive beskyttet. I stedet kom FN's folk på jorden til at fungere som en ufrivillig allieret for den srilankanske hær. Titusindevis af tamilere var blevet lokket ind i en såkaldt 'sikkerhedszone', der derefter blev bombet af Sri Lankas hær. Og disse overtrædelser af enhver af krigens regler var ikke fejl begået af enkelte rådne æbler eller i kampens hede. Det var helt systematiske overgreb som del af en tilsyneladende veltilrettelagt militær strategi for at afslutte den 26 år lange borgerkrig en gang for alle. Derfor dræbte de ikke bare mænd i den kampdygtige alder, men også de kvinder, der kunne huse dem, og de børn, der potentielt kunne følge i deres fodspor.

Hvordan kunne det ske, uden at verdenssamfundet reagerede? Det simple svar er, fordi ingen så med. Da regeringen og den militære ledelse besluttede at sætte den endelige offensiv ind, sendte de alle internationale vidner ud og forbød alle journalister adgang til området. Ifølge hærens egen udlægning fordi den ikke kunne garantere for deres sikkerhed. Ifølge de FN-folk, der måtte forlade deres poster, mens grædende civile tiggede dem om at blive, var det fordi det som stod for, ikke kunne tåle verdens øjne. Som FN's tidligere talsmand i Sri Lanka, Gorden Wiess, siger i dokumentarfilmen: "De ville fjerne internationale vidner til det, der skulle komme. Og FN accepterede det.”

\section{Terrorkortet}

Op til offensiven i 2009 havde regeringen altid trukket terroristkortet med succes. "Vi har vores terrorister, som vi må tackle på vores måde, ligesom i tackler jeres eksplosive plageånder i Irak, Afghanistan og Tjetjenien', har været et yndet argument fra den srilankanske regerings side. Og længe gik det godt. De Tamilske Tigre røg først på den amerikanske terrorliste, der jo har en særegen tendens til ret ukritisk at blive kopieret i Europa. Medierne spillede med og forspildte aldrig en chance for at fortælle (i øvrigt i strid med sandheden), at De Tamilske Tigre var 'selvmordsbomberens opfindere'.

Man kan mene, hvad man vil om graden af legitimitet i tamilernes krav, ligesom der er al mulig grund til at fordømme metoderne. LTTE er en dybt brutal organisation med brug af børnesoldater og systematisk intimidering af den tamilske civilbefolkning. Men faktum er, at virke- 
ligheden blev forvredet, da tamilernes kamp efter 11 . september blev sat ind i det større terrorbillede. $\mathrm{Og}$ væk var beretningen om 26 års undertrykkelse og diskussionen om et folks ret til kulturel selvbestemmelse. Det skabte grobund for omverdenens stiltiende accept af, hvad der nu i stigende grad erkendes som krigsforbrydelser.

Hvis verdenssamfundet nu skal spille en aktiv rolle i processen med at cementere freden, er det helt afgørende at kræve en undersøgelse af krigens afslutning. Retssagerne mod diverse afrikanske diktatorer giver ikke meget håb for en handlekraftig international retsorden, men hvis der overhovedet er noget legitimitet tilbage i domstolen i Haag, kan Mahinda Rajapakse og hans hærledelse vise sig som oplagte kandidater til en tur på anklagebænken.

Det er dog næppe realistisk, men der er andre måder at presse regeringen i Colombo. Sanktionskortet blev i EU's bukselomme alt for længe under krigen, men i 2010 blev Sri Lanka frataget den særlige status, som landet nød i samhandel med EU.

\section{Løsning ikke fundet}

Paradoksalt nok kan freden skygge for de systematiske diskrimineringer og overtrædelser. Så længe der var en åben konflikt blev verden - om end ofte i meget begrænset omfang - nødt til at have et øje på Sri Lanka, nødt til at fordømme overgrebene, og den var tvunget til at diskutere med regeringen i Colombo fx i forbindelser med forhandlinger om handelsaftaler med EU.

$\mathrm{Nu}$ er 'freden' her, men det farligste er, at en generation af nu voksne mænd og kvinder aldrig har kendt til andet end konflikt. De er hurtige til at gribe til våben. $\mathrm{Og}$ mens 'bevægelsen' måske er overfladisk svækket af, at mange af dens ledende figurer mistede livet eller blev sat ud af spillet ad andre veje, gør man klogt i ikke at underkende den i den tamilske befolkning dybt forankrede fremmedgjorthed over for den srilankanske stat.

Organisatorisk er bevægelsen heller ikke for alvor svækket. I de tamilske områder, mest udpræget selvfølgelig Jaffne-halvøen har der altid været flydende grænser mellem LTTE og diverse NGO'er.

Den endelige løsning på konflikten i Sri Lanka er ikke fundet. $\mathrm{Og}$ ser vi ikke snart et kursskifte i Colombo, kan vi hurtig ende i en situation, hvor våbnene igen bliver opfattet som den eneste løsning for tamilerne.

Anna von Sperling er global medarbejder ved dagbladet Information. 